Ryszard Klamut*

DOI: $10.2478 / v 10241-012-0031-5$

\title{
Assessment of decisions in the context of life attitudes
}

\section{ABSTRACT}

Presented article attempts to show sense of life perspective as a determinant of decision making. It is assumed that the sense of life perspective described as life attitudes is significant in assessment of decision problem defined in the predecision phase of the decision making process. The predicted dependence was analysed in three categories of decision: self-development, financial and voting. The research was conducted on two groups of 186 and 86 participants. Two methods were used in the research: the Life Attitude Profile -Revised (LAP-R) and the Decision Assessment Questionnaire. In statistical analysis, the canonical correlation analysis was used. The scores show that the life attitudes (especially: Purpose, Coherence, Life Control and Existential Vacuum) are correlated with the assessment factor (especially: Cognitive Analysis and Affective Assessment) of each tested category of decision. However, the most significant relationship is found in the self-development decision.

KEYWORDS: life attitudes, sense of life, decision assessment, self-development decision, financial decision, voting decision, canonical analysis

* Correspondence regarding the paper should be sent to: Ryszard Klamut, Rzeszow University of Technology, Faculty of Management, Department of Humanities, ul. Poznańska 2, 35-959 Rzeszow, e-mail: rklamut@prz.edu.pl 


\section{INTRODUCTION}

The issue of decision-making is strongly embedded in scientific considerations. It can be stated that generally people are beings who are still making decisions (Biela, 1976; Coombs, Davies \& Tversky, 1970; Tyszka, 2010). Decisions are routine or irregular. Some are very easy but others are difficult and or very important, giving weighty consequences for entire life. They are different and, in theoretical considerations, they can be differentiated taking a subject as the criterion. They can be distinguished into financial, managerial, political, voting, purchasing, self-development, holiday decisions etc. (Decrop, 2006; Lau \& Redlawsk, 2007; Nosal, 2001).

From a psychological perspective the topic of decisions making is seen particularly as an issue of cognitive psychology. Decisionmaking is treated like a specific way of information processing, with the aim of choosing one, the most useful alternative of at least two (Crozier \& Ranyard, 1997; Hastie \& Dawes, 2001). This is a mental process distinguished by phases, in general by three: pre-decision, decision and post-decision (Hastie \& Dawes, 2001; Svenson, 1992). Different information processes take place in each of these phases. In the first one the purpose is to prepare a diagnosis of the decision issue and to define alternatives in the field of its importance, availability and consequences, which it may bring. Kozielecki (1969) points out that the pre-decision processes consist of the evaluation of expected results, subjective probability rating and assessment of the risk level. These processes are supposed to obtain the data required to make an effective decision. The essential aspect of the second phase is to accomplish an appropriate choice, to take the most beneficial alternative in the subjective point of view of the decision maker. Lastly in the third phase, the assessment of the results of choices and the consequences which occur (Hastie \& Dawes, 2001; Rohrbaugh \& Shanteau, 1999; Svenson, 1996). 
Despite many categories of decisions they can be described using the same formal characteristics (Hastie \& Dawes, 2001). This possibility is an effect of mental activity. The mind creates mental representations of subjects, phenomena or situations for (better) understanding of reality and it also plays a part in the decision making process (Crozier \& Ranyard, 1997; Hastie \& Dawes, 2001; Verplanken \& Svenson, 1997).

Characterizing decisions into many dimensions is used, like difficulty-easiness, importance-unimportance, possibility of consequences, quantity and quality (positive or negative) consequences, singularity or recurrence of decisions, riskiness and cognitive as well as emotional involvement (Hastie \& Dawes, 2001; Jost \& Sidanius, 2004; Kemdal \& Montgomery, 1997; Lewicka, 1997; Verplanken \& Svenson, 1997). Lau (2003) claimed that the process of judgment is the essence of the pre-decision phase and that judgment identifies the mapping of many even ambiguous elements and forms a general perceptive system of each situation of decision.

The list of characteristics of perceived situations of decisions described above is not finished, however, it shows some dimensions used to define a decision, which is made. These characteristics can be reduced to such dimensions as Strain of the decision and Involvement in decision making (Klamut, Sommer \& Michalski, 2010). The former dimension, the mental strain, is referred to as perceived difficulties, consequences and assesses the level of riskiness. It results from the essential characteristics included in the risky decision description. While the latter, the involvement refers to basic manners of judgment of reality - emotional and rational (Epstein, 1990; Lewicka, 1997; Lau, 2003; Verplanken \& Svenson, 1997). It is related to Epstein's Cognitive-Experiential Self-Theory (CEST) and the levels of data processes -affective assessment and cognitive analysis (Epstein, 1990).

Nonetheless, defining of the decision problem is not easy. The decisions made by people are very often risky. A decision maker 
does not acquire sufficient data for a comprehensive or even adequate cognition of a situation of the decision and prediction of possible results of analyzed alternatives in the decision making process (Kühberger, 1997; Sokołowska \& Pohorille, 2000).

This is one difficulty to be managed by the decision maker. The other is a different determinant influencing the entire decisionmaking process beginning with defining the decision problem. The factors modifying decision-making are divided into objective (such as life situation, time pressure, pressure of other people and stimulus strength) and subjective (such as personality traits and perceptional biases) (McCrae \& Costa, 2008; Strelau, 2008; Winter, 2003). The objective factors are independent of the decision makers. They only can control them, which requires a cognitive effort. The subjective factors can be organized using the perspective of personality. Most commonly three levels of personality description are shown: firstly: unchangeable, biologically conditioned, like temperamental traits, secondly: environmentally conditioned, specified individual adaptation manners, like goals, motives, attitudes and thirdly: the most individual, and changeable characteristic describing self concept, cognitive model of the world and relationship between the world and I (e.g. sense of life) (McCrae \& Costa, 2008; Pervin, 1996; Strelau, 2008).

Winter (2003) depicted the model of the subjective determinants in the context of decision making distinguishing four elements: cognitions, traits, motives and social context. They are described in two dimensions: first - observable and public or inner, inferential and second - relatively stable across situations and time or highly dependent on contexts. Traits are stable and observable elements of personality in which extraversion, energy level as well as neuroticism are included as typical variables. Cognitions are stable and interferential and include such various categories as mental representations, beliefs, values, attitudes, self-concept, and conceptions of the nature of the world, truth, beauty and goodness. Motives, which are situation dependent 
and not observable, include regulating mechanisms, defensive mechanisms, habits, goals and other specified motives pursuing important purposes. Lastly, the social context, the element of personal functioning observable and situation dependent, includes large range of the factors like gender, class, culture, race and ethnicity, age, generation, wealth etc. Winter's proposition is a very broad perspective of the conditions of human activity. The presented determinants have an essential impact on the efficacy of the decision making process. They specify the issue of the decision and cause focusing on some pieces of information as well as being the sources of many biases (Hastie \& Dawes, 2001; Tversky \& Kahneman, 1974).

Among determinants of human activity and also decision making a global evaluation of the own life is considerable as well. In Winter's model it can take place as cognitions and can be described as life attitudes. Life attitudes for one's own life are defined as experiences of sense of life (Reker, 1992). Frankl defines the sense of life as the state of subjective satisfaction of a person, which is as a result of intentional activity, directed to values (Frankl, 1988). The sense of life is the notion from the existential psychology perspective, however as the global evaluation of life includes the cognitive perspective as well (Reker \& Wong, 1988; Reker, 2000). Reker (2000) points out that existential psychology assumes that to be human means to make choices, to pursue goals and to act with individuality. The state of experienced sense of life is connected with positive evaluation of specific activity. In a lot of research the sense of life was treated as a category included in the description of goal activity and risk taking (e.g. Klamut, 2002; Porczyńska, 2006; Próchniak, 2005; Van Ranst \& Marcoen, 2000; Zaleski, 1991).

Reker and others point out that the sense of life is a complex phenomenon and describe three components: cognitive, emotional and motivational (Reker \& Wong, 1988; Van Ranst \& Marcoen, 2000). The cognitive component is referred to assign the mean- 
ing for life experiences. Everyone creates individual system of beliefs and considers the ultimate purpose of human life and asks existential questions concerning the order of the universe. The sense of life in the cognitive aspect is a subjective interpretation of individual being and a system of beliefs is the map of the one's reality. The motivational component is connected with needs, goals as well as a value system and focuses human activity on significant, meaningful purposes, whereas the emotional component includes life satisfaction, fulfillment and happiness.

The three distinguished elements are the same as in attitude description (Aronson, Wilson \& Akert, 1994; Zimbardo \& Leippe, 1991). According to Reker (1992) the sense of life is just built by six basic attitudes towards oneself and life in general. These life attitudes are: purpose, coherence, life control, death acceptance, goal seeking and existential vacuum. The purpose refers to having life goals, a sense of direction from the past, through the present to the future. It provides thrust and direction to one's life. The coherence refers to having integrated and consistent understanding of one's self, others and life in general. It gives order and reason for existence. The life control is perceived as freedom to make life choices with personal responsibility and to have internal control of life events. The death acceptance refers to a lack of anxiety about death and acceptance of death like a natural aspect of life. The goal seeking is some kind of desire to escape from life routine and to search for new experiences and eagerness to get more out of life as well. The existential vacuum refers to a lack of sense of life, a lack of goals and also a feeling of boredom (Reker, 1992).

The category of life attitudes allows us to combine the existential perspective with the cognitive perspective. If indeed the experience of sense of life is the determinant of peoples activity, it is also connected with the decision making process.

The presented article aims to examine if this relationship is significant. Three categories of decisions are analyzed in the research for testing the predicted dependence. There are: self-development, 
financial and voting decisions. They are different in subject and level of the basic characteristics of decisions such as dynamics, uncertainty, complexity and openness (Coombs, Davies \& Tversky, 1970; Nosal, 2001; Kozielecki, 1977). However, it is worth assuming also the fifth important characteristic of decisions. Its consequences for the life of decision makers are seen as specific or global.

In this context it can differentiate the tested decisions. The self-development decisions concern choosing the best activity for a subjective individual. They are dynamic, risky, complex, open and with global consequences. The financial decisions, which concern funding, are also dynamic, risky, complex and open but with specific consequences. The voting decisions, the third category of the decisions tested in the presented research concerns choosing a preferred political party in general elections in Poland, 20 October 2007. They are dynamic, risky, complex, close and with global consequences for decision makers.

The main question in this article is if the relationship between the life attitudes and decision-making exists and, if it is true, in which way the life attitudes relate with the assessment of different categories of decisions. The hypotheses are set as follows:

1. The schema of relationship is similar independently of decision categories;

2. The differences in schemas of relationships between different decision categories have a quantitative character, not qualitative;

3. Personally important decisions (self-development) are connected with intensity of life attitudes to a large extent than the other decisions. 


\section{METHOD}

\section{Participants}

The research was conducted on two groups of people. The first one described decisions in two categories: self-development and financial and the second one described voting decisions. All participants were undergraduate students in the Faculty of Management and Marketing at the Rzeszow University of Technology, Poland. There were 186 participants in the first group and 85 in the second one. Both groups were very similar in the description of social characteristics. The percentage of men and women was $76 \%: 24 \%$ in the first group and $78 \%: 22 \%$ in the second, respectively. The average age of the first group $19.78(\mathrm{SD}=0.78)$ and of the second group $22.74(\mathrm{SD}=4.1)$, respectively.

\section{Measures}

Two methods are used in the presented research. They are the Polish version of the Life Attitude Profile -Revised (LAP-R) and the Decision Assessment Questionnaire. The Life Attitude Profile -Revised (LAP-R) was created by Reker (1992) and adapted to the Polish version by Klamut (2010). This method measures the attitudes towards important aspects of life and personal activity in the perspective of the sense of life. It consists of 48 items on the Likert's scale of reply and is made up of six simple and two composite scales (Reker, 2000). In the presented research only simple scales were used. They are equivalent to the life attitudes described above: Purpose (PU), Coherence (CO), Life Control (LC), Death Acceptance (DA), Existential Vacuum (EV) and Goal Seeking (GS). Alfa coefficients for the scores on these scales in the Polish version were found to be .77, .74, .72, .83, .70 and .71, respectively (Klamut, 2010).

The Decision Assessment Questionnaire was created for describing the characteristics of cognitive representations of decision raised in the pre-decision phase. It was put together in 
Polish based on Osgood's semantic differential scale and gives the possibility for describing different decisions. It consists of 28 characteristics and has a seven-point Likert format scale of reply.

The exploratory factor analysis resulted in four factors identified as Difficulty, Uncertainty, Cognitive Analysis and Affective Assessment (Klamut, Sommer \& Michalski, 2010). Difficulty refer to assessment of complexity and difficulty of the decision made. Uncertainty pointing out the level of the intensity of the feeling of riskiness appeared as being in an uncertain situation and associated with time pressure. The subjective assessment of the consequences of the decision made is also significant. Cognitive Analysis describes the intensity of cognitive efforts included in decision-making and activated level of awareness. It refers to the rational system in the Epstein theory. Affective Assessment, lastly, quantifies the level of evaluation of the decision made on the continuum from bad, non-effective, non-essential and with negative emotions to essential, effective and with positive emotions. It refers to the experiential system in the Epstein theory (Epstein, 1990). Factor scores are the sums of item ratings. Alfa coefficients for the scores of these scales were found to be $.87, .81$, .74 and .73 , respectively. Distinguished scales form two factors resulted in exploratory factor analysis. Difficulty and Uncertainty built the factor identified as Strain and Cognitive Analysis and Affective Assessment built the factor identified as Involvement.

\section{Procedure}

The participants answered the items in the Polish version of LAP-R as well as noted decisions made in the questionnaire and then filled out the Decision Assessment Questionnaire relating to each noted decision, separately. The canonical correlation analysis was used in this research (Ferguson \& Takane, 1989). Canonical correlation was performed between a set of decision assessment variables and a set of life attitudes variables. Correlations between 
canonical variables were analyzed in each category of decisions, separately.

\section{RESULTS}

The scores used in the above way gave the possibility of statistical analysis. In each category of decisions the first pair of canonical variates was significant. The relationship between the set of decision assessment variables and the set of life attitudes variables was found to be the highest level of all tested categories in the self-development decision ( $C R=.50$; Chi Square(24)=68.41; $\mathrm{p}<.001)$ and in the others it was found at the following levels: in the financial decision $(C R=.32$; Chi Square $(24)=38.95 ; \mathrm{p}<.05)$ and in the voting decision $(\mathrm{CR}=.49$; Chi Square $(24)=38.88 ; \mathrm{p}<.05)$.

The results of the canonical analysis concerning the self-development decision show that both canonical variates extract about $36 \%$ of their own variances. However the canonical variate of decision assessment set composed of Uncertainty, Cognitive Analysis and Affective Assessment extracts only $8.8 \%$ of the variance in the second canonical variate composed of such life attitudes as Purpose, Coherence, Life Control and Existential Vacuum. Similarly, the canonical variate of the life attitudes explains the variance in the canonical variate of decision assessment at the same level, $8.9 \%$. In the decision assessment canonical variate, Affective Assessment was the dominating variable (.97) whereas the life attitudes canonical variate is most strongly influenced by Existential Vacuum (-.81), Purpose (.77) and Coherence (.71) (see Table 1). 
Table 1. Canonical loadings for the canonical variates in the self-development decisions

\begin{tabular}{|l|c|}
\hline \multicolumn{1}{|c|}{ Scales } & Coefficients \\
\hline Difficulty & .00 \\
\hline Uncertainty &. .41 \\
\hline Cognitive Analysis & .56 \\
\hline Affective Assessment & .97 \\
\hline \multicolumn{2}{|c|}{} \\
\hline Purpose & .77 \\
\hline Coherence & .71 \\
\hline Death Acceptance & .10 \\
\hline Goal Seeking & .22 \\
\hline Life Control & .59 \\
\hline Existential Vacuum &. .81 \\
\hline
\end{tabular}

$\mathrm{N}=186$

The category of financial decisions points also to the statistically significant relationship between the canonical variates, although it is less important. The level of explanations of the variance in their own canonical variates are similar to that in the previous category and is $34.9 \%$ for the canonical variate of decision assessment and $32.4 \%$ for the canonical variate of the life attitudes. Nonetheless, the level of explanation of the variance in one canonical variate by the other is low $(3.6 \%$ and $3.3 \%$ ). The dominating variable in the set of the decision assessment variables is Cognitive Analysis (.84) and in the set of the life attitudes variables are Purpose (.83) and Life Control (.84) (see Table 2). 
Table 2. Canonical loadings for the canonical variates in the financial decisions

\begin{tabular}{|l|c|}
\hline \multicolumn{1}{|c|}{ Scales } & Coefficients \\
\hline Difficulty &. .17 \\
\hline Uncertainty &. .45 \\
\hline Cognitive Analysis & .84 \\
\hline Affective Assessment & .67 \\
\hline \multicolumn{2}{|l|}{} \\
\hline Purpose & .83 \\
\hline Coherence & .55 \\
\hline Death Acceptance & .09 \\
\hline Goal Seeking & .28 \\
\hline Life Control & .84 \\
\hline Existential Vacuum &. .40 \\
\hline
\end{tabular}

$\mathrm{N}=186$

Table 3. Canonical loadings for the canonical variates in the voting decisions

\begin{tabular}{|l|c|}
\hline \multicolumn{1}{|c|}{ Scales } & Coefficients \\
\hline Difficulty & .37 \\
\hline Uncertainty & .58 \\
\hline Cognitive Analysis & .97 \\
\hline Affective Assessment & .69 \\
\hline \multicolumn{2}{|l|}{} \\
\hline Purpose & .87 \\
\hline Coherence & .82 \\
\hline Death Acceptance & .40 \\
\hline Goal Seeking & .16 \\
\hline Life Control & .62 \\
\hline Existential Vacuum &. .62 \\
\hline
\end{tabular}

$\mathrm{N}=85$

The variance in their own canonical variates in the voting decisions is predictable at the level $47.0 \%$ for the set of decision 
assessment variables and $39.9 \%$ for the set of the life attitudes variables. The canonical variate of the decision assessment explains $11.3 \%$ of the variance in the second variate whereas the set of life attitudes variables extracts $9.6 \%$ of the variance in the oposite variate at the significant level. The most important variable in the set of decision assessment variables is Cognitive Analysis (.97) and in the life attitudes canonical variate the most important are Purpose (.87) and Coherence (.82) (see Table 3).

\section{DISCUSSION}

The relations between life attitudes and cognitive representation of decision making were studied in the presented article. It was assumed that the category of the sense of life built by the life attitudes is significant in the assessment of decision issue in different categories of decisions.

The obtained data confirms the set assumptions and show that correlations are significant in each category of decisions. The life attitudes are largely related to more positive decision assessment (lack of difficulties, less uncertainty and high level of emotional and rational involvement). Analyzing the significance of particular life attitudes in the decision-making, Purpose and Coherence (as the most important) and Life Control and lack of Existential Vacuum were found as the important factors. They all define the state of experience of sense of life or, in other words, personal meaning (Frankl, 1988; Reker, 1992, 2000). Distinguished attitudes characterize the goal oriented, personal activity which combines with cognitive analysis in the decision making process.

The most significant characteristics in the decision assessment aspect are Cognitive Analysis and Affective Assessment, describing Involvement in decision-making. This aspect of the decision assessment is more connected with personal meaning. The characteristics of Strain are lower, only the lack of Uncer- 
tainty is significant but on a lower level than the characteristics of Involvement. It is interesting that the most important in the assessment of self-development decisions is Affective Assessment and in the other kinds of decision - Cognitive Analysis. The selfdevelopment decisions are more personal and unique as well as significant for entire life (Walesa, 1988), hence intensity of Affective Assessment is larger than in the other decisions. Whereas, Cognitive Analysis plays the main role in more specified decisions. Analyses of gains and losses (Kahneman \& Tversky, 1979; Tyszka, 2010) are more significant in that decision and show an analytical information process as the most important element associated with the sense of life perspective in decision making. Nevertheless, in the financial decisions, dependence between the decision assessment and the sense of life characteristics is rather low.

The differences between the tested categories of decisions have not qualitative but quantitative character and refer to the strength of the correlation between the decision assessment and the life attitudes independently of the analyzed categories of decision. Probably, this relationship will be seen in another kinds of decision and will be relevant at lower levels in decision specific and not important personally.

It can be stated that the life attitudes are one of the determinants influencing the decision making process, therefore it is worth including the sense of life perspective into broad, multifactor models of decision making. Not only such basic factors as biological, temperamental ones and others, closely connected with decision making processes like cognitive structures, but also such individual factors as subjective understanding and experiencing of reality (real world) are significant in decision making. The personal meaning or, in other words, the experience of the sense of life, is important to understand oneself and to undertake an intentional activity. The high level of experienced sense of life is useful in the better organization of activity, more useful planning 
the future, higher risk acceptance and making more risky decisions (Frankl, 1988; Klamut, 2002; Nosal, 2001; Próchniak, 2005; Reker, 2000; Van Ranst \& Marcoen, 2000; Zaleski, 1991).

The obtained results allow to widen the look on the conditions of decision making. It can be stated that presented Winter's complex model organizing determinants of decision making (Winter, 2003) needs to be completed. It can be extended including, besides the two existing dimensions: observable - inner and stable - dependent on contexts, the third one defined as accuracy generality. Among many determinants of the decision making process the third dimension allows to differentiate those referring to a specific situation or phenomenon and others referring to one's life and life generally. For example, concerning needs, it can distinguish to the requirement of food and eating to be happy; concerning values - it can include well-known diversity between the instrumental or ultimate values.

The phenomenon of the sense of life in categories of general life attitudes can be used in cognitive or rather cognitive-existential description of human activity and can be used in creating more precise psychological models of human functioning.

\section{REFERENCES}

Aronson, E., Wilson, T. D., \& Akert, R. M. (1994). Social Psychology: The Heart and the Mind. New York: Harper Collins.

Biela, A. (1976). Informacja a decyzja. [Information and decision]. Warszawa: PWN. Coombs, C. H., Dawes R. M., \& Tversky, A. (1970). Mathematical psychology: An elementary introduction. Englewood Cliffs, New Jersey: Prentice-Hall.

Crozier, R., \& Ranyard, R., (1997). Cognitive Process Models and Explanations of Decision Making. In R. Ranyard, W. R. Crozier, \& O. Svenson (eds), Decision Making: Cognitive Models and Explanations (pp. 5-20). New York-London: Routledge.

Decrop, A. (2006). Vacation Decision-Making. Wallingford, Oxfordshire: CABI Publishing. 
Epstein, S., (1990). Cognitive-Experiential Self-Theory. In L. Pervin (ed.), Handbook of Personality: Theory and Research (pp. 165-192). New York: Guilford Press.

Ferguson, G. A., \& Takane, Y. (1989). Statistical analysis in psychology and education (6th ed.). New York: McGraw-Hill.

Frankl, V. E., (1988). The will to meaning. Foundations and applications of logotherapy. New York: Meridian book.

Hastie, R., \& Dawes, R.M. (2001). Rational choice in an uncertain World. The psychology of judgment and decision making. Thousand Oaks, London, New Delhi: Sage Publications.

Jost, J. T., \& Sidanius, J. (2004). Challenges of Decision-Making. In J. T. Jost \& J. Sidanius (eds), Political psychology: key readings (pp. 241-243). New York: Psychology Press.

Kahneman, D., \& Tversky, A. (1979). Prospect Theory: An Analysis of Decision under Risk. Econometrica, 47(2), 263-292.

Kemdal, A. B., \& Montgomery, H. (1997). Perspectives and emotions in personal decision making. In R. Ranyard, W. R. Crozier \& O. Svenson (eds), Decision Making: Cognitive Models and Explanations (pp. 72-89). New York-London: Routledge.

Klamut, R. (2002). Cel - czas - sens życia. [Goal - time - sense of life]. Lublin: Towarzystwo Naukowe KUL.

Klamut, R. (2010). Kwestionariusz Postaw Życiowych KPŻ. Podręcznik do polskiej adaptacji kwestionariusza Life Attitude Profile - Revised (LAP-R) Gary'ego T. Rekera. [Life Attitude Questionnaire KPŻ. Manual for the Polish version of the Life Attitude Profile - Revised (LAP-R) by Gary T. Reker]. Warszawa: Pracownia Testów Psychologicznych Polskiego Towarzystwa Psychologicznego.

Klamut, R., Sommer, H., \& Michalski, K. (2010). Aktywność obywatelska we wspótczesnym społeczeństwie demokratycznym. Wybrane zagadnienia. [Citizen activity in modern democratic society. Selected issues]. Kraków: SEITON

Kozielecki, J. (1969). Psychologia procesów przeddecyzyjnych. [Psychology of predecision processess]. Warszawa: PWN.

Kozielecki, J. (1977). Psychologiczna teoria decyzji. [Psychological theory of decision]. Warszawa: PWN.

Kühberger, A. (1997). Theoretical conceptions of framing effects in risky decisions. In R. Ranyard, W. R. Crozier \& O. Svenson (eds), Decision Making: Cognitive Models and Explanations (pp. 128-144). New York-London: Routledge. 
Lau, R. R. (2003). Models of Decision-Making. In D. O. Sears, L. Huddy \& R. Jervis (eds), Oxford handbook of political psychology (pp. 19-59). Oxford: University Press.

Lau, R. R., \& Redlawsk, D. P. (2007). How voters decide: information processing during election campaigns. New York: Cambridge University Press.

Lewicka, M. (1997). Is hate wiser than love? Cognitive and emotional utilities in decision making. In R. Ranyard, W. R. Crozier \& O. Svenson (eds), Decision Making: Cognitive Models and Explanations (pp. 90-106). New York-London: Routledge.

McCrae, R. R., \& Costa, P. T. (2008). The Five-Factor Theory of Personality. In O. P. John, R. W. Robins \& L.A. Pervin (eds.). Handbook of Personality. Theory and Research (pp. 159-181). New York: Guilford Press.

Nosal, C. S. (2001). Psychologia myślenia i dziatania menedżera. [Psychology of thinking and activity of manager]. Kraków: Wydawnictwo AKADE.

Pervin, L. A. (1996). The science of personality. New York: Wiley.

Porczyńska, A. (2006). Tendencja do podejmowania ryzyka a doświadczanie szczęścia. [Tendency of risk taking and happiness experience]. In M. Goszczyńska \& R. Studenski (eds), Psychologia zachowań ryzykownych. Koncepcje, badania, praktyka [Psychology of risk behaviour. Conceptions, research, practise]. (pp. 145-170). Warszawa: Wydawnictwo Akademickie ŻAK. Próchniak, P. (2005). Podejmowanie ryzyka a sens życia człowieka. [Risk taking and sense of life]. Słupsk: Pomorska Akademia Pedagogiczna.

Reker, G. T. (1992). Life Attitude Profile-Revised (LAP-R). Manual. Peterborough, Ontario: Students Psychologists Press.

Reker, G. T. (2000). Theoretical perspective, dimensions, and measurement of existential meaning. In G. T. Reker \& K. Chamberlain (eds), Exploring Existential Meaning. Optimizing human development across the life span (pp. 39-55). Thousand Oaks, London, New Delhi: Sage Publication.

Reker, G. T., \& Wong, P. T. P. (1988). Aging as an individual process: Toward a theory of personal meaning. In J. E. Birren \& V. L. Bengtson (eds), Emergent theories of aging (pp. 214-246). New York: Springer Publishing.

Rohrbaugh, C. C., \& Shanteau, J. (1999). Context, Process, and Experience: Research on Applied Judgment and Decision Making. In F. Durso (Ed.), Handbook of Applied Cognition (pp. 115-139). New York: John Wiley.

Sokołowska, J., \& Pohorille, A. (2000). Models of Risk and Choice: Challenge or Danger? Acta Psychologica, 104, 339-369.

Strelau, J. (2008). Temperament as a regulator of behavior: After fifty years of research. New York: Eliot Werner Publications. 
Svenson, O. (1992). Differentiation and consolidation theory of human decision making: a frame of reference for the study of pre- and post-decision processes. Acta Psychologica, 80, 143-168.

Svenson, O. (1996). Decision Making and the Search for Fundamental Psychological Regularities: What Can Be Learned from a Process Perspective? Organizational Behavior and Human Decision Processes, 65(3), 252-267.

Tversky, A., \& Kahneman, D. (1974). Judgment under Uncertainty: Heuristics and Biases. Science, 185(4157), 1124-1131.

Tyszka, T. (2010). Decyzje. Perspektywa psychologiczna i ekonomiczna. [Decisions. Psychological and economic perspectives.] Warszawa: WN Scholar.

Van Ranst N., \& Marcoen A. (2000). Structural components of personal meaning in life and their relationship with death attitudes and coping mechanisms in late adulthood. In G. T. Reker \& K. Chamberlain (eds), Exploring Existential Meaning. Optimizing human development across the life span (pp. 59-74). Thousand Oaks, London, New Delhi: Sage Publication.

Verplanken, B., \& Svenson, O. (1997). Personal involvement in human decision making. Conceptualisations and effects on decision processes. In R. Ranyard, W. R. Crozier, O. Svenson (eds), Decision Making: Cognitive Models and Explanations (pp. 40-57). New York-London: Routledge.

Walesa, C. (1988). Psychologiczna analiza decyzji życiowo-doniosłych - empiryczne badania wybranych grup młodzieży. [Psychological analysis of life-significant decisions - empirical research of young people]. In A. Biela, Z. Uchnast \& T. Witkowski (eds), Wykłady z psychologii w Katolickim Uniwersytecie Lubelskim 1985/86 [Lectures of psychology in Catholic University of Lublin 1985/1986]. (pp. 277-350). Lublin: RW KUL.

Winter, D. G. (2003). Personality and political behavior. In D. O. Sears, L. Huddy, R. Jervis (eds), Oxford handbook of political psychology (pp. 110-145). Oxford: University Press.

Zaleski, Z. (1991). Psychologia zachowań celowych. [Psychology of goal oriented activity]. Warszawa: PWN.

Zimbardo P. G., \& Leippe M. (1991). Psychology of Attitude Change and Social Influence. New York: McGraw-Hill. 